\title{
COMPARISON BETWEEN TRADITIONAL METHODS AND REAL TIME PCR FOR DETECTION OF E.COLI IN BOVINE MEAT PRODUCTS
}

\author{
EMAN M. ZAKARY ${ }^{*}$ and MARIUM FOUAD ${ }^{* *}$ \\ *Biotechnology Department, Animal Health Research Institute, Egypt, Dokki. \\ ${ }^{* *}$ Bacteriology Department, Animal Health Research Institute, Assiut, Egypt.
}

\section{ABSTRACT}

Received at: $27 / 5 / 2013$

Accepted: 8/7/2013
This study was performed to compare the prevalence of $E$.coli in minced meat and sausage using traditional methods and real time PCR. A total of 100 samples of minced meat and sausage (50 of each) were collected from different supermarket in Giza and Assiute governorates. The results using traditional methods recorded as $25 \%$ and $15 \%$ as positive $E$.coli from minced meat and sausage respectively, while the incidence of $E$. coli $\mathrm{O} 157$ recorded as $4 \%$ and $2 \%$ from minced meat and sausage respectively. The incidence of E. coliO 157 by using real time PCR recorded as $8 \%$ and $6 \%$ from minced meat and sausage respectively. The melting curve appeared at $\left(82^{\circ} \mathrm{C}\right)$ for E. coli $\mathrm{O} 157$ by using SYBR green Real time PCR.

Key words: Real time PCR sybrgreen, Ecoli 0157

\section{INTRODUCTION}

Meat and meat products are considered as an excellent source of high quality animal protein, vitamins especially B complex and certain minerals, especially iron (Mohammed, 2011). They are considered as an ideal culture medium for growth of many organisms because of high moisture content, high percentages of nitrogenous compounds. Meat products may be contaminated with microorganisms from meat handlers, which carry of pathogenic microorganism during the processes of manufacturing, packing and marketing. (Fratmico et al., 2005). Contamination of raw meat is one of the main sources of food borne illnesses (Bhandare et al., 2007; Podpecan et al., 2007). E. coli are considered the most commensally living microorganism in the elementary tract of nearly all animal and wild animals as well as human. Escherichia coli is a predominant facultative anaerobe of the human colonic flora. The organism is typically colonises the infant gastrointestinal tract within hours of life, and thereafter $E$. coli and the host derive mutual benefit (Nataro and Kaper, 1998).

Most E. coli live commensally in the gastrointestinal tract of most mammals (Rahimi et al., 2012) also do not cause disease in human, but certain types may cause diarrhea or more serious forms of illness. $E$. coli is one of the most frequent causes of some of the many common bacterial infections of man such as urinary tract infection, neonatal meningitis, cholecstitis, bacteremia, cholangitis, traveler's diarrhea and pneumonia
(Ochoa and Cleary, 2003; Ammar, 2005), E.coliO157: $\mathrm{H} 7$ is the most common member of a group of pathogenic E coli strains (Rahimi et al., 2012) and other serotypes of Shiga toxin producing E. coli, are food borne pathogens of primary concern (Mor-Mur and Yuste, 2010). Escherichia coli O157:H7 has emerged as an important foodborne pathogen of considerable public health concern (Kansouzidou and levidiotou, 2003), the severity of infection which it causes and an infectious dose which may be as low as 10 organisms. In an outbreak study reported by (Willshaw et al., 1994) contamination levels in an implicated product were reportedly as low as 2 cells per $25 \mathrm{~g}$. This pathogen has been implicated in a number of high-profile outbreaks in the USA (Bell et al., 1994), Scotland (Michino et al., 1998) as well as in many sporadic cases of infection. Cattle are still regarded as one of main reservoirs of E. coli O157:H7, with the pathogen occurring in the faeces (Chapman et al., 1997), rumen (Van Donkersgoed et al., 1999), hide (Elder et al., 2000). E. coli $O$ 157:H7 also act as etiological agents of haemorrhagic colitis. In some cases, complications may occur, such as haemolytic uremic syndrome and thrombotic thrombocytopenic purpura. EHEC other than E. coli $O 157$ have been increasingly associated with such complications. The severity of the illness and the low infective dose ( $<100$ organisms) make E. coli O157:H7 among the most serious food borne pathogens (Acheson, 2003; Meng et al., 2007) meat can be contaminated during the slaughter operation and processing (Juneja and Marmer, 1999; El-Gohary, 1993). 
At the end of the human food chain, numerous studies have reported the presence of E. coli O157: $H 7$ usually at low prevalences, on retail meats. A recent study in France (Vernozy-Rozand et al., 2002) reported $0.12 \%(4 / 3450)$ samples positive for $E$. coli O157:H7 in large-scale processed minced beef, while studies of butcher's shops in a range of countries have reported higher values i.e. $3.8 \%$ (6/160) in Argentina (Chinen et al., 2001); 2.3\% $(5 / 211)$ in Switzerland (Fantelli and Stephan, 2001); and $1.1 \%(36 / 3216)$ in the UK (Chapman et al., 2000). In the Netherlands, (Heuvelink et al., 1999) reported an overall prevalence of $1.1 \%(6 / 571) E$. coli $0157: H 7$ in minced beef products. Other studies found very different results, ranging from $16.8 \%$ (50/296) E. coli O157:H7 samples in Washington State, USA (Samadpour et al., 2002) to a study by (Tarr et al., 1999) which did not recover the pathogen from 1400 retail ground minced beef samples from six stores in Seattle, USA. With the exception of the study of Vernozy-Rozand et al. (2002) the above studies merely determined presence or absence of E. coli O157:H7, usually after enrichment, and in general, little data are available on the numbers of this pathogen in retail meat products.

Traditional culture methods for detecting microorganisms in food are based on the incorporation of the food sample into a nutrient medium in which the microorganisms can multiply. These conventional test methods easily adaptable, very practical, and generally inexpensive (Chart, 1998).

Although not lacking in sensitivity, they can be laborious and depend on the growth of the microorganisms in different culture media (preenrichment, selective enrichment, selective plating, identification), which may require several days before results are known. Products that are minimally processed have an inherently short shelf life, which prevents the use of many of these conventional methods. Therefore, extensive research has been carried out over the years to reduce assay time through the use of alternative methods for detecting foodborne microorganisms and reduce the amount of manual labor by automating methods whenever possible (Feng, 2007; Betts and Blackburn, 2009; Jasson et al., 2010).

Long duration enrichments are often used due to the low number of pathogenic microorganisms that tend to be present in food samples. Although previous enrichment is a limitation in terms of assay speed and precludes quantification of the original contaminant, it provides essential benefits, such as diluting the effects of inhibitors, allowing the differentiation of viable from nonviable cells, and allowing for the repair of cell stress or injury that may have resulted during food processing (Jantzen et al., 2006; Wu 2008). Hence, it would be difficult to completely eliminate enrichment culture from the process of pathogen detection in foods (Feng, 2007).

SYBR Green 1 is a DNA-intercalating dye that is widely used for real-time PCR applications (Monis PT et al, 2004; Stampi et al., 2004). There are advantages and disadvantages to using SYBR Green I for real-time PCR detection. The advantages include high detection sensitivity and speed (30 -40 min per 40 cycles). The rapid real time PCR based method was performed very well compared to the conventional method. It is fast reproduciblethe results can be obtained quickly (in about $3 \mathrm{~h}$ ) (Bottari et al., 2006), simple, specific and sensitive way to detect nucleic acids, which could be used in clinical diagnostic tests in the future (Pochop et al., 2012). The disadvantage is that it binds to any double-stranded DNA (Epsy et al., 2006).

Compared with the classical urine culture methods, real time PCR is more rapid and can detect smaller number of bacteria; which would otherwise undetectable (Yoshimasa, 2002). Real-time PCR has been used for the rapid and reliable detection of E. coli $\mathrm{O} 157$ in retail red meats (Suo et al., 2010; Perelle et al., 2007). The culture in these methods is time consuming (up to 3-5 days) and not suitable for routine screening of large samples (Savoye et al., 2012). More recently, real time PCR is being increasingly used as a rapid sensitive and specific molecular diagnostic technique for the testing and identification of food pathogens from biological and environmental samples (Bellin et al., 2001).

\section{MATERIALS and METHODS}

\section{Materials and methods}

Samples Collection: One hundreds of minced meat and sausage samples (50 of each) were collected random from different supermarket in Assuite and Giza governorates. They were placed in containers and put in refrigerated vehicles during transportation. Samples are taken randomly from boxes outside of our region and conveyed respecting the freezing temperature of $-18{ }^{\circ} \mathrm{C}$ to the Regional Veterinary Laboratory (Gershwin, 1990). Ten g of samples +90 $\mathrm{ml}$ MacConkey broth after incubation at $37^{\circ} \mathrm{C}$ for 24 hours were inoculated onto macConkey agar and incubated at $37^{\circ} \mathrm{C}$ for 24 hours, Pink colonies of a lactose fermenting organism appeared. Single typical well isolated lactose fermenting colonies were tested by culturing on Eosin Methylene blue (EMB), and incubated at $37^{\circ} \mathrm{C}$ and $44^{\circ} \mathrm{C}$ for 24 hours. The greenish metallic sheen by reflected light and dark purple centers by transmitted light. Similarity isolated lactose fermenting colonies were tested for sorbitol 
fermentation by culturing on sorbitol MacConkey agar and incubated at $37^{\circ} \mathrm{C}$ over night. On sorbitol MacConkey ,colourless or pale colonies were considered as non fermenters of sorbitol and pinkcolonies as sorbitol fermenters. Morphological examination were done according to (Finegold and Martin, 1982).

Culture and Isolation of Escherichia Coli O157:

Enrichment cultures for each sample were carried out by combining $25 \mathrm{~g}$ of each sample with $225 \mathrm{ml}$ of buffered peptone water supplemented into a stomacher bag, homogenized for two $\mathrm{min}$ and incubated at $37^{\circ} \mathrm{C}$ for $16-18 \mathrm{~h}$. After incubation, the isolates belonging to $E$. coli were cultured on Sorbitol Mac Conkey medium for detecting non sorbitol variants. This test required the identification guides to the enterohemorrhagic E .coli (EHEC) strains. The strains metabolizing sorbitol are excluded, however the rest of the strains are tested for their immunological confirmation by the method of (Koneman, 1992).

Serological Identification: All biochemically identified non sorbitol fermenting colonies from the sorbitol-Mac Conkey Agar (SMAC) were subjected to slide agglutination with the $E$. coli $\mathrm{O} 157$ antisera (Difco) and the agglutinating colonies were further processed for definitive confirmation (Quinn, 1994; Edwards, 1972; Jasson et al., 2010).

E. coli O157: H7 antigen determination all sorbitol non-fermenting, indole positive, 4Methylumbeliferyl-B-D glucuronide (MUG) negative colonies were examined by latex agglutination (Wellcolex, Merseyside, UK). These beads are coated with antibodies which bind to any O157: H7 antigens on the test organisms, forming a visible antigenantibody precipitate (De Boer and Heuvelink,
2000). Colonies giving a precipitation reaction were confirmed as E. coli $O 157$ positive.

DNA extraction. DNA was extracted from the meat samples use extraction DNAeasy Tissue Kit (JenaBiosience cat \# pp-206s) Kit protocol for the extraction of DNA from tissuse. The extracted DNA stored at $-20^{\circ} \mathrm{c}$ until use in real time PCR assays.

\section{Real-time PCR}

Methods are the simplest and least expensive method and enables products to be identified by their different Tm, by analysing the melting curve of the amplicon post-PCR besides detection of target DNA during amplification. (Washington et al., 2004; Malorny et al., 2004).

Amplfication and detection were carried out in Stratagene the maxima SYBR Green qPCR master mix (2x) Rox solution provided (\#K 0251) was used in all. Amplifications were performed using a Stratagene MX 3000 P with software version 4. For SYBR-Green amplifications, a dissociation step was added to improve amplification specificity. TaqMan and SYBR-Green reactions were carried out in a final volume of $25 \mu \mathrm{l}$ with appropriate final concentrations of primers, primer use in E coli O 157 in real time PCR as in (Table 1) the primer concentrations were as follows: $10 \mathrm{pmol} / \mathrm{ul}$. (Paton and Paton, 1998). The reaction was run and melting of the amplification products curve analysis. To evaluate the efficiency of the amplification, a standard curve was constructed using the threshold cycle $(C T)$ Each reaction was run with the following cycle conditions (Table 2). The specificity of the reaction is given by the detection immediately after the last reaction cycle. The melting curve was visualized with the software.

Table 1: Primer used in detection of (E .coli O157)

\begin{tabular}{|c|c|c|c|c|}
\hline Primer & organism & $\operatorname{Tm~C}$ & Sequence & Position from start of \\
\hline & & & $5 \_3$ & E.coli gene \\
\hline$O 157 F$ & E. coli 0157 & 56.9 & TCTGCGCTGCTATAGGATTAGC & $701-722$ \\
\hline \multirow[t]{2}{*}{ O157A } & & 56.0 & & \\
\hline & & & CTTGTTTCGATGAGTTTATCTGCA & $926-903$ \\
\hline
\end{tabular}


$\underline{\text { Assiut Vet. Med. J. Vol. } 59 \text { No. } 138 \text { July } 2013}$

Table 2: Real time PCR condition for amplification of E.coli O157.

\begin{tabular}{ccll}
\hline $\begin{array}{c}\text { Program PCR } \\
\text { sybr green } \\
\text { protocol }\end{array}$ & $\begin{array}{l}\text { Target } \\
\text { temperature }{ }^{\circ} \mathrm{C}\end{array}$ & Hold time (s) & No. of cycle \\
\hline Denaturation & 95 & 600 & $\begin{array}{l}\text { One } \\
\text { cycle }\end{array}$ \\
\hline Amplification & 95 & 15 & $\begin{array}{l}35 \\
\text { cycle }\end{array}$ \\
\cline { 2 - 3 } & 54 & 5 & $\begin{array}{l}\text { One } \\
\text { cycle }\end{array}$ \\
\cline { 2 - 3 } $\begin{array}{c}\text { Melting curve } \\
\text { analysis }\end{array}$ & 72 & 12 & \\
\cline { 2 - 3 } & 95 & 15 & \\
\hline & 65 & 30 & \\
\hline
\end{tabular}

\section{RESULTS}

From the analysed meat samples, 40 out of 100 recorded as sorbital positive Escherichia coli were characterized by classical phenotypic tests in all samples. Whereas, only $3 \%$ sorbitol negative
Escherichia coli was identified and isolated, rod, gram negative nonsorbitol fermenting and produce indole. The agglutinating test showed that this strain is belonging to the serotype of Escherichia coli 0157.

Table 3: The Incidence of $E$.coli $O 157$ in meat products samples

\begin{tabular}{|c|c|c|c|c|c|}
\hline \multirow[t]{3}{*}{ Type of samples } & \multirow[t]{3}{*}{$\begin{array}{c}\text { Number of ex } \\
\text { samples }\end{array}$} & \multicolumn{2}{|c|}{$\begin{array}{l}\text { Positive results using } \\
\text { traditional methods }\end{array}$} & \multicolumn{2}{|c|}{$\begin{array}{c}\text { Positive results of } E \text {.coli } O 157 \\
\text { using Real time PCR }\end{array}$} \\
\hline & & \multirow[b]{2}{*}{ E.coliE.coli $\mathrm{O}$} & & & \\
\hline & & & 157 & No & $\%$ \\
\hline Minced meat & 50 & 25 & 2 & 4 & 8 \\
\hline Sausag & 50 & 15 & 1 & 3 & 6 \\
\hline Total & 100 & 40 & 3 & 7 & 7 \\
\hline
\end{tabular}

From data in (Table 3) recorded that 40 out of 100 samples (minced meat and sausage 50 of each) recorded as $E$. coli but 3 only out of 40 recorded as E.coli 0157.

By using the real time PCR from minced meat samples recorded that 4 out of $50(8 \%)$ as E. coli $O 157$ while 3 out of $50(6 \%)$ of sausage samples recorded as $E$.coli $O 157$.
From Fig (1) Using sybrgreen appeared the amplification curve appeared from the 22 cycles as in minced meat and sausage samples because the amount of DNA is sufficient enough to appeared at 22 cycles comparison with control positive native organ (serology unit in AHRI Dokki, Giza), while the melting curve appeared at $82^{\circ} \mathrm{C}$ as in Fig. (2) 
Fig. (1) Amplification of samples comparison with positive control (native organ from AHRI serology unit)

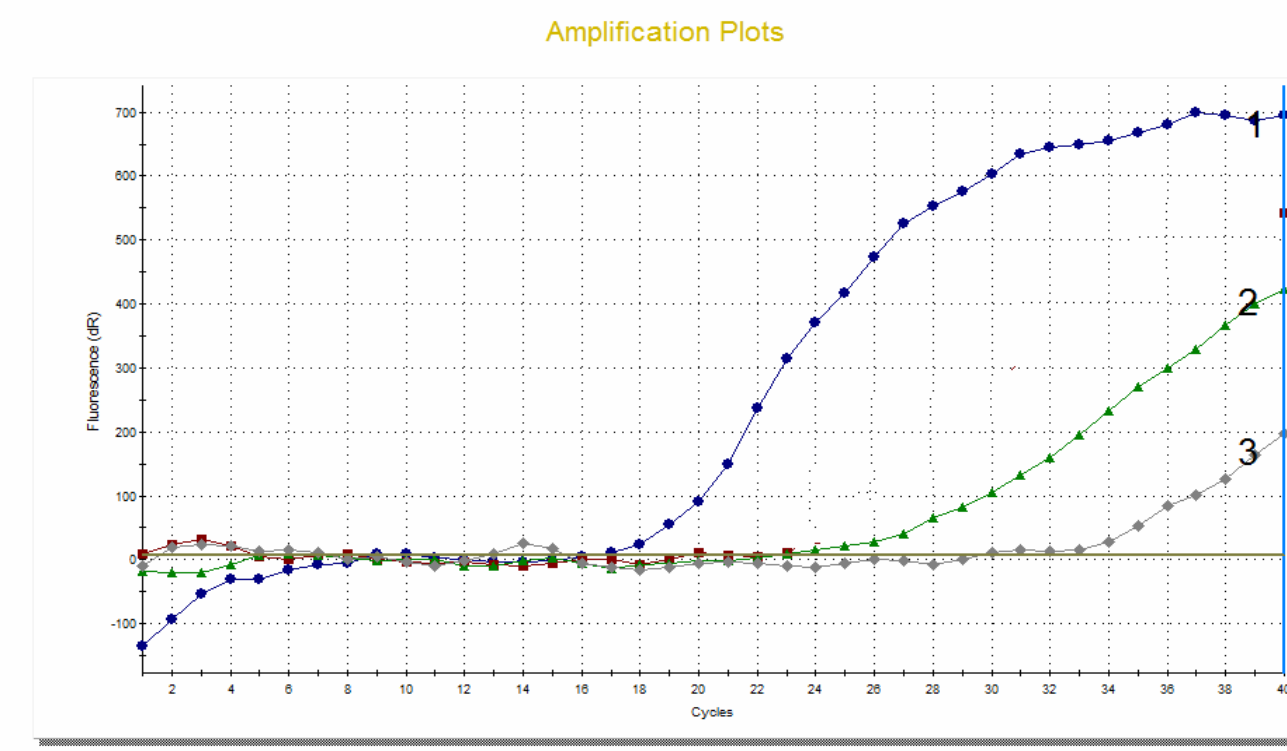

- 1-Control +veE coliO157 native strain from serological unit in AHRI 2-Minced meat samples 3-sausage samples

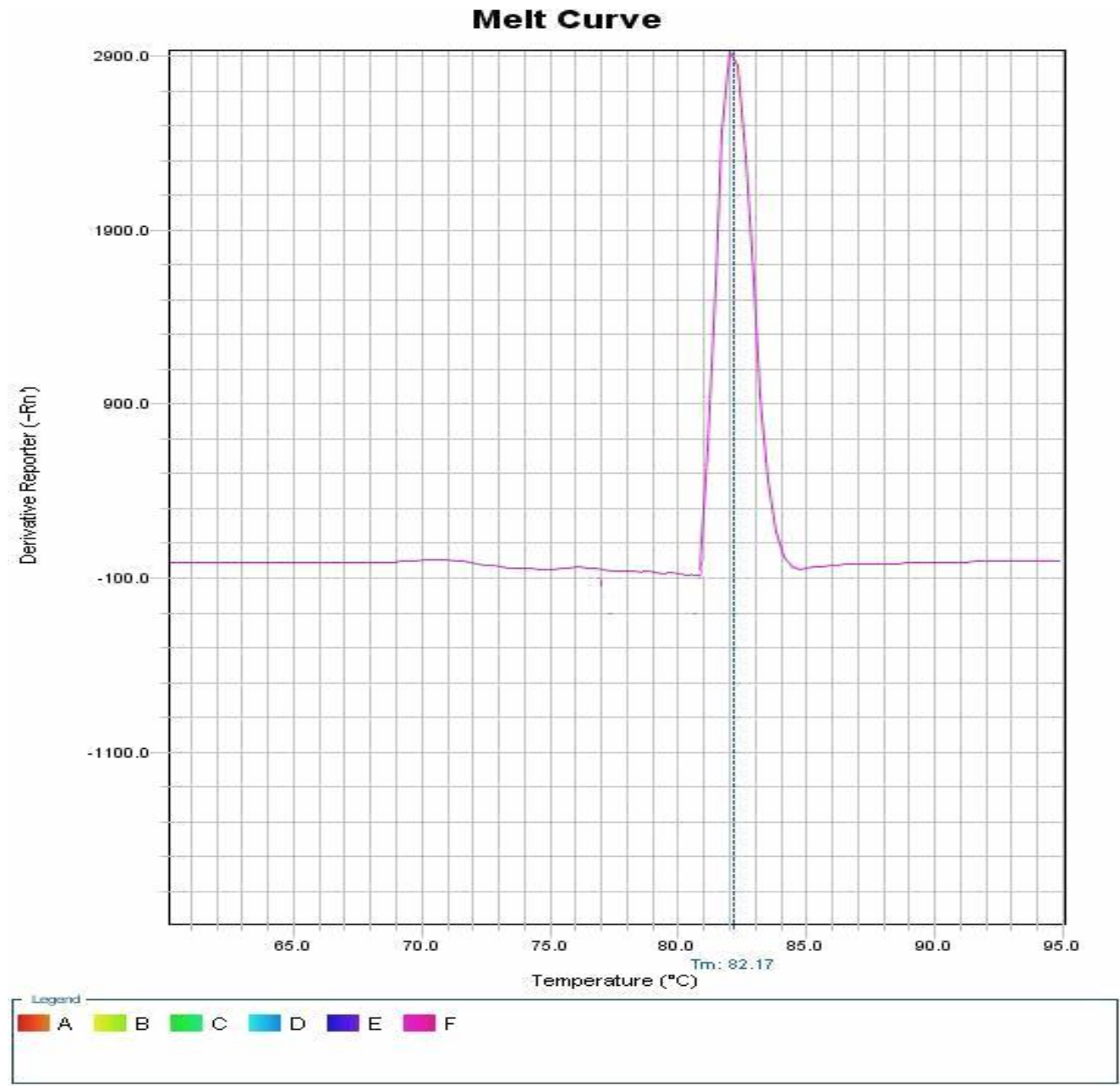

Fig. (2) Melting curve analysis of all positive reactions revealed that variation in melting temperatures were low for $E$.coli $\mathrm{O} 157$ specific PCR fragments $\left(82^{\circ} \mathrm{C}\right)$ 


\section{DISCUSSION}

Meat has been linked to consumer health problems, Meat products are recognized as a major source of food born pathogens that cause food poisoning in humans. The most important pathogens associated with meat products are E.coli (Borch et al., 1996).

Currently the most important pathogens associated with meat products are Escherichia coli (Darwish, 1991; Borch et al., 1996). Meanwhile, all examined meat products samples showed high contamination level of $E$.coli in examined meat products may indicates unsanitary conditions of raw meat production, preparation and handling. Undercooked meat products have caused many food poisoning incidents associated with Escherichia coli which is present in the faeces, intestines and hide of healthy cattle from where it can potentially contaminate carcass meat during the slaughtering processes (Duffy et al., 2003).

Because of the low dose of E. coli O157 needed to cause infection, sensitive and rapid detection methods for $E$. coli $\mathrm{O} 157$ in food samples are necessary in food industry to ensure a safe supply of foods. Several studies have reported the prevalence of E.coli O 157 in meat product as (Dontorou et al., 2003) who recorded E. coli $\mathrm{O} 157$ from $0.5 \%$ foods including minced meat and sausages.

The sensitive detection of E. coli $\mathrm{O} 157$ has been developed over recent years with the use real time PCR. There are different reference methods for detecting E. coli $\mathrm{O} 157$ in foods (United states Department of Agriculture Food Safety and Inspection Service 2010 a, b; Feng and Weagant 2011; AOAC International 2011).

By using traditional methods, out of 100 samples of meat products, 40 samples $(40 \%)$ were positive for Escherichia coli. The obtained results was higher than values reported in studies conducted in France $(0.12 \%)$ (Vernozy-Rozand et al., 2002) and the UK (1.1\%) (Chapman et al., 2000; Fantelli and Stephan, 2001) (2.3\%) and higher than reported in a study in Argentina (3.8\%) (Chinen et al., 2001); (Seran et al., 2012) who recorded the percentage as $8.82 \%$. And higher than El-Taher-Omyma (1998) (25\%); Saleh (2001) (16\%).

On the otherhand, the data of the present study is nearly similar to the data reported by El-Mossalami (2003) (40\%). The prevalence in minced meat indicated that the presence of this pathogen in red meats indicates improper or insufficient hygiene management both at the farm and during the slaughtering and meat handling process Seran et al. (2012).
Moreover the incidence of Escherichia coli in the examined sausage samples $(30 \%)$ was lower than the findings recorded by Zaki-Eman (1990) and ElKhateib et al. (1994) they recorded E. coli in sausage with incidence $44 \%$ and $48 \%$ respectively, but higher than the incidence which obtained by (Mohamed, 2011) who recorded $12 \% E$.coli from sausage. The variation in the results obtained by different investigators may be due to difference in manufacturing practices, handling and difference in time of exposure.

In our study $E$.coli $\mathrm{O} 157$ was detected as $8 \%$ from minced meat and $6 \%$ from sausages. In comparison with other countries, the prevalence reported in this study is slightly higher than reported from Greece $0.5 \%$ (Dontorou et al., 2003), Morocco $2.8 \%$ (Badri et al., 2009; Abd El-Atty and Meshref, 2007).

In our study the interest was based on the search of E. coli $\mathrm{O} 157$ in meat considering that consumption of red meat and especially beef has risen steadily and the stock continues decreasing in Algeria, in order to know if the cold chain was observed during the transport of foods. Apart from the study by Chahed et al. (2006) on the contamination assessment levels in bovine carcasses with this bacteria in Algeria, where the author has detected two strains of serotype O157: H7, Allerberger et al. (2001).

By using real time PCR, the incidence of E.coli $\mathrm{O}$ 157 in minced meat is reached to $8 \%$. The obtained result is higher than the results $(0.17 \%$ and $1.4 \%)$ that obtained by Walsh et al. (1997) and Duffy et al. (1998), respectively on the otherhand our result is consistent with finding recorded by Lindqvist et al. (1998), Little and de Louvois (1998) and Tarr et al. (1999).

Table (3) showing that the Percentage of E. coli in examined samples using real time is higher than that recorded using traditional methods, this difference may be attributed to the higher sensitivity of the real time PCR and propability of presence of dead organism in the samples. Using real-time PCR, proved that it was able to detect very small per reaction of E. coli $O 157$ (Elizaquível and Aznar, 2008 and Narang et al., 2009).

SYBR Green Real Time PCR was determined by the definition of the melting temperature of the PCR product obtained (De Medici et al., 2003). The limit of quantification of real-time PCR with food samples is around $10^{3}-10^{4} \mathrm{CFU} / \mathrm{g}$ (Rodriguez-Lazaro and Hernandez, 2006; Navas et al., 2006; Jasson et al., 2010). Most samples taken from throughout the food supply chain are usually contaminated with fewer pathogen cells (normally less than $100 \mathrm{CFU} / \mathrm{g}$ ). These new detection methods are the necessary technologies 
that will substantially improve our food safety once integrated in the HACCP (Bhunia, 2008). Microbiological analysis of foods is based on the detection of microorganisms by visual, biochemical, immunological, or genetic means, either before enrichment (quantitative or enumerative methods) or after enrichment (qualitative methods, also known as presence/absence tests).

The complexity of food materiles remains the major obstacle to the development of effective sampling and rapid testing methods (Feng, 2007). Long duration enrichments are often used due to the low number of pathogenic microorganisms that tend to be present in food samples. The presence of a single peak indicates the specificity of the reaction and when more than one amplicon is obtained, they can be distinguished by differences of at least $1^{\circ} \mathrm{C}$ in Tm Lipsky et al. (2001); Ririe et al. (1997). Identical amplicons were detected by real time method are similar to findings by (Catarame et al., 2003). The melting curve of E. coli is $82^{\circ} \mathrm{C}$ nearly to (Hanlon et al., 2004) who recorded it at $80.2{ }^{\circ} \mathrm{C}$. Meat products should be properly handled, and packed in sterile polyvinyl wrappers (Abong'o BO and Momba MN 2009).

Future possibilities for this work is to successfully Not only does this technique provide tools for highly sensitive and specific detection of the organism in clinical specimens, but certain characteristics including virulence, toxins and antimicrobial resistant genes may also be determined (Ram et al., 2008).

\section{CONCLUSION}

It is very important detection method for $E$. coli is necessary for the health of the consumers. Hygienic awareness should be applied for personnel whom involved in handling and preparing of food at factories, home or restaurants. Careful handling and through cooking of raw and frozen meat, regardless of market source by the consumers is required to prevent food born illness. Finally, Hazard Analysis Critical Control Point (HACCP) procedures should be adopted during all steps of manufacture, handling as well as storage of meat products to produce safe and high quality products as well as ensuring compliance with legislation.

The real-time PCR reaction can be easily used in the qualitative and quantitative detection of these bacteria after an anterior enrichment or even directly from the alimentary matrix, as long as the bacterial quantity is detectable by the used instrument, however the costs of the reagents and of the necessary tools are pretty high. The molecular methods are specific, sensitive and reproducible, which makes it easier for the specialists who work in laboratories.
The sensitivity of detection with SYBR-Green may therefore be compromised by the formation of primer-dimers, lack of specificity of the primers, primer concentration and the formation of secondary structures in the PCR product. All of these factors could lead to the creation of unexpected doublestranded DNA products, which would incorporate SYBR-Green and register a fluorescent signal.

The dissociation curves showed that the amplification product was very specific. The result indicated that real-time PCR was 1000 times more sensitive than traditional methods.

The process of selecting an appropriate method must consider the main criteria of the sensitivity of analysis, the time of detection, and the specificity of the test (Table3). The cornerstone of any method is its accuracy. This consists of the sensitivity and the specificity. The intent in developing a rapid assay is to reduce the time required to obtain an accurate result. Qualitative detection (presence/absence) tests are used if information concerning the presence of an organism in a specified quantity of food is required. The sensitivity of these tests is then defined by the quantity of food examined (Stannard, 1997; Jasson et al., 2010). In many cases, the requirement of detection is less than one cell per $25 \mathrm{~g}$ of food, as small numbers of some pathogens may be sufficient to cause disease. Sensitive quantitative detection is usually achieved by traditional culture methods (Table 3). Thus, rapid method still lack sufficient sensitivity for direct testing (Feng, 2007). Traditional culture methods may require many days, resulting in very long assay durations. Most rapid methods for the detection of pathogens or toxins can be done in a few minutes to a few hours or at the utmost 1 day (Table 3).

However, many detection systems need an enrichment, and positive results must be confirmed by the appropriate official method, which involve culturing, in many instances (Feng, 2007). In spite of this, commercially available rapid detection methods, such as ELISA, LFD, and PCR, have substantially shortened the total time of the detection assay when compared to conventional methods (Table 3) (Leon-Velarde et al., 2009). They are, therefore, of great use in the rapid analysis of food with the goal of ensuring that only negative samples or lots are sent to market (Bohaychuk et al., 2005). A major disadvantage of alternative methods over culture methods is that most rapid methods involve damaging the cells. Therefore, viable cells for confirmation and further characterization can only be obtained by carrying out repeat analyses using standard culture procedures (Feng, 2007). 


\section{REFERENCE}

Abd El-Atty NS, S. and Meshref, AM. (2007): Prevalence of salmonella and $E$ coli $\mathrm{O} 157$ in some foods. BS. Vet. Med. J. November $5^{\text {th }}$ Scientific Conference p.73-78.

Abong'o, BO, and Momba, MN. (2009): Prevalence and characterization of Escherichia coli O157:H7 isolates from meat meat products sold in Amathole District, Eastern Cape Province of South Africa. Food Microbiol. Apr; 26(2): 173-6.

Acheson, D.W.K. (2003): Emerging foodborne enteric pathogens. In B. Caballero, L.C. Trugo, and P.M. Finglas (Eds.). Encyclopedia of food sciences and nutrition, $2^{\text {nd }}$ edn., pp. 2062-2069. London: Academic

Allerberger, F.; Wagner, M.; Schweiger, P.; Rammer, HP.; Resch. A.; Dierich, MP.; Friedrich, AW. and Karch, H. (2001): Escherichia coli O157 infections and unpasteurisedmilk. EuroSurveill. 2001 Oct;6 (10): 147-51.

Ammar, M.A.M. (2005): Spoilage and pathogenic microorganisms in traditional meat products in Assuit.M.V.Sc. Thesis, (Meat Hygiene), Faculty of Veterinary Medicine, Assiut University, Egypt.

AOAC INTERNATIONAL (2011): Performance Tested Methods sm Validated Methods. http://www.

aoac.org/testkits/testedmethods.html. Last updated: October 2011. Accessed 18 November.

Bardi, S.; Filliol, L.; Carle, L.; Hassar, M.; Fassouane, A. and Cohen, N. (2009): Prevalence of virulence genes in $\mathrm{E}$ coli isolated from food in casblance (Moracco). Food Control, 20: 560-564.

Bell, B.P.; Goldoft, M.; Griffin, P.M.; Davis, M.; Gordon, D.C.; Tarr, P.L.; Bartleson, C.A.; Lewis, J.H.; Barrett, T.J. and Well, J.G. (1994): A multistate outbreak of Escherichia coli O157:H7-associated bloody

diarrhoea and haemolyticuraemic syndrome from hamburgers. The Washington experience. J. Am. Vet. Med. Assoc. 272, 1349-1353.

Bellin, T.; Pulz, M.; Matussek, A.; Hempen, H.G. and Gunzer, F. (2001): Rapid detection of enterohemorrhagic E.Coli by real time PCR with fluorescencent hybridization probes. Journal of clinical Microbiology 39, 370-374

Betts, R. and Blackburn, CW. (2009): Detecting pathogens in food. In: Foodborne pathogens: hazards, risk analysis and control, $2^{\text {nd }}$ edn. Edited by: Blackburn CW, McClure PJ. Woodhead Publishing, Oxford, UK. pp. $17-65$.
Bhandare, S.G.; Sherikar, A.T.; Paturkar, A.M.; Waskar, V.S. and Zende, R.J. (2007): A comparisonofmicrobial contamination on sheep/goat carcasses in a modern Indian abattoir and traditional meat shops. Food Control, 18: 854-868.

Bhunia, AK. (2008): Biosensors and bio-based methods for the separation and detection of food-borne pathogens. Adv Food Nutr Res 54: $1-44$.

Bohaychuk, VM.; Gensler, GE.; King, RK.; Wu, JT. and McMullen, LM. (2005): Evaluation of detection methods for screening meat and poultry products for the presence of foodborne pathogens. J Food Prot. 2005 Dec;68(12): 2637-47

Borch, E.; Nesbakken, T. and Christenes, H. (1996): Hazard identification in swine slaughter with respect to foodborne bacteria. Int. J. Food Microbiol., 30: 9-25.

Bottari, B.; Ercolini, D.; Gatti, M. and Neviani, E. (2006): Application of FISH technology for microbio-logical analysis: current state and prospects. Appl Microbiol Biotechnol 73: 485-494.

Catarame, T.M.G.; O'HYanlon, K.A.; Duffy, G.; Sheridan, J.J.; Blair, Lo.S. and McDowell, D.A. (2003): Optimization of enrichment and plating procedures for the recovery of E. Coli O111 and O26 from minced beef .Journal of applied Microbiology 95, 949-957.

Chahed, A.; China, B.; Mainil, J. and Daube, G. (2006): Prevalence of enteroheamorrhaic Esherichiacoli on bovine carcasses in Algeria. J. Appl. Microbiol., 101: 361-368.

Chart, H. (1998): Toxigenic E. coli. J. Applied Microbiol., 84: 775-865.

Chinen, I.; Tanoro, J.D.; Miliwebsky, E.; Lound, L.H.; Chillemi, G.; Ledri, S.; Baschkier, A.; Scarpin, M.; Manfredi, E. and Rivas, $M$. (2001): Isolation and characterisation of Escherichia coli O157:H7 from retail meats in Argentina. J. Food Prot. 64, 1346-1351.

Chapman, P.; Siddons, C.A.; CerdanMalo, A.T. and Harkin, M.A. (1997): A one year study of Escherichia coli O157 in cattle, sheep, pigs and poultry. Epidemiol. Infect. 119, 245-250.

Chapman, P.; Siddons, C.A.; CerdanMalo, A.T. and Harkin, M.A. (2000): A one year study of Escherichia coli 1 O 57 in raw beef and lamb products. Epidemiol. Infect. 124, 207-213.

Darwish, A.M.; Niazi, Z.M. and Zaki, E.M. (1991): Escherichia coli in meat products. Vet. Med. J., Giza, 39(3): 841-851

De Boer, E. and Heuvelink, A.E. (2000): Methods for the detection and isolation of Shiga toxinproducing E. coli. J. Appl. Microbiol. Symp. Suppl. 88, 1335-1435. 
De Medici, L.; Croci, E.; Delibato, S.; Pasquale, Di; Filetici, E. and Toti, L. (2003): "Evaluation of DNA extraction methods for use in combination with SYBR green I real-time PCR to detect Salmonella enterica serotype Enteritidis in poultry," Applied and Environmental Microbiology, vol. 69, no. 6, pp. 3456-3461.

Dontorou, C.; Papadopoulou, C.; Filioussis, G.; Economou, V. and Apostolou, I. (2003): Isolation of Escherichia coli O157:H7 from foods in Greece. Int. J. Food Microbiol., 82: 273-279.

Duffy, G.; McEvoy, J.M.; Sheridan, J.J.; Kilbride, B. and Garvey, $P$. (1998): Unpublished Data from the National Food Centre, Teagasc, Ashtown, Dublin 15, Ireland.

Duffy, G.; Cagney, C.; Crowley, H. and Sheridan, J.J. (2003): A Nationwide Surveillance Study on E. coli 0157:H7 and Enterobacteriaceae in Irish Minced Beef Products.

Edwards, P.R. and Ewing, W.H. (1972): Identification of Enterobactericeae. Burgess publCo.Minnece polis, Minnesota, p.103-104.

El-Gohary, A.H. (1993): Sausage and minced meat as a source of food poisoning microorganisms to man. Assiut, Vet. Med. J., 30(59).

El-Khateib, F.T.; Moustafa, S. and Hassanrin, K. (1994): Salmonella and Enteropathogenic Escherichia coli in some locally manufactured meat products. Assiut. Vet. Med. J., 31(61).

El-Mossalami, E.I.K. (2003): Risk assessment of ready prepared meat products. Ph.D. Thesis, Faculty of Veterinary Medicine, Cairo University, Egypt.

El-Taher-Omyma, M. (1998): Bacteriological quality of chicken meat products. M.V.Sc. Thesis, Faculty of Veterinary Medicine, Cairo University, Egypt. FAO, 1992.Food and Agriculture Organization of United Nation, Manual of Food Quality Control.

Elder, R.O.; Keen, J.E.; Siragusa, G.R.; BarkocyGallagher, G.A.; Koohmaraie, M. and Laegreid, W.W. (2000): Correlation of enterohaemorrhagic Escherichia coli O157 prevalence in faeces, hides and carcasses of beef cattle during processing. Proc. Natl. Acad. Sci. 97, 2999-3003.

Elizaquível, P. and Aznar, R. (2008): A multiplex RTi-PCR reaction for simultaneous detection of Escherichia coli O157:H7, Salmonella spp. and Staphylococcus aureus on fresh, minimally processed vegetables. Food Microbiol., 25, 705-713.

Epsy, MJ. (2006): Real-Time PCR in clinical microbiology: applications for routine laboratory testing. Clinical Microbiology Reviews. 19 (1):165-256
Fantelli, K. and Stephan, R. (2001): Prevalence and characteristics of shigatoxin-producing Escherichia coli and listeriamonocytogenes strains isolated from minced meat in Switzerland. Int. J. Food Microbiol. 70, 63-69.

Feng, P. (2007): Rapid methods for the detection of foodborne pathogens: current and nextgeneration technologies. In: Food microbiology, fundamentals and frontiers, 3rd edn. Edited by: Doyle MP, Beuchat LR. ASM Press, Washington, D.C. pp 911-934.

Feng, P. and Weagant, SD. (2011): Diarrheagenic Escherichia coli . Bacteriological Analytical Manual, Chapter 4A http://www.fda.gov/food/scienceresearch/labo ratorymethods/bacteriologicalanalyticalmanualbam/ucm070080.htm

Finegold, S.M. and Martin, W.J. (1982): Bailey and Scotts Diagnostic Microbiology $6^{\text {th }}$ Edn. C.V. Mosby and Co. St. Louis .P.107.

Fratmico, P.M.; Bhunia, A.K. and Smith, J.L. (2005): Foodborne Pathogens in, Microbiology and Molecular Biology, Caister and Academic Press, Wymondham, Norfolk, UK, pp: 273.

Gershwin, L.J. (1990): The physiochemical and biological basis of immunity. In: Biberstein, E.L., Zee,Y.C. (Eds.): Review of Veterinary Microbiology. Blackwell Scientific Publications, Boston, USA. 29-30.

Hanlon1, T.M.G.; Catarame1, G.; Duffy1, I.S.; Blair2 and McDowell, D.A. (2004): RAPID detection and quantification of $\mathrm{E}$. coli O157/O26/O111 in minced beef by real-time PCR. Journal of Applied Microbiology 96, 1013-1023

Heuvelink, AE.; Zwartkruis-Nahuis, JTM.; Beumer, RR.; de Boer, E. (1999): Occurrence andsurvival of verotoxin-producing Escherichia coli O157 in meats obtained from retail outlets in the Netherlands. J. Foodprot .62: 1115-1120.

Jantzen, MM.; Navas, J.; de Paz, M.; Rodríguez, B.; da Silva, WP.; Nuñez, M. and MartínezSuárez, JV. (2006): Evaluation of ALOA plating medium for its suitability to recover high pressure-injured Listeria monocytogenes from ground chicken meat. Lett. Appl. Microbiol. 43: 313-317.

Jasson, V.; Jacxsens, L.; Luning, P.; Rajkovic, A. and Uyttendaele, M. (2010): Review. Alternative microbial methods: An overview and selection criteria. Food Microbiol. 27:710-730.

Juneja, V.K. and Marmer, B.S. (1999): Lethality of heat to Escherichia coli O157:H7: D- and zvalue determinations in turkey, lamb and pork. Food Research International 32: 23-28. 
Kansouzidou, and Levidiotou, S. (2003): Isolation of Escherichia coli O157:H7 from foods in Greece International Journal of Food Microbiology Volume 82, Issue 3, 15 May, Pages 273-279 .

Koneman, E.W.; Allen, S.D.; Dowell, V.R.; Janda, W.H. and Sommers, H.M. (1992): Color atlas and Textbook of Diagnostic Microbiology. 4TH Ed., J.B. Lippincott CO., New York

Leon-Velarde, CG.; Zosherafatein, L. and Odumeru, $J A$. (2009): Application of an automated immunomagnetic separation-enzyme immunoassay for the detection of Salmonella enterica subspecies enterica from poultry environmental swabs. J. Microbiol. Methods. 79(1): 13-17.

Lindqvist, R.; Antonsson, A.K.; Norling, B.; Persson, I.; Ekstrom, A.C.L.; Fager, U.; Eriksson, E.; Lofdahl, S. and Norberg, P. (1998): The prevalence of verocytotoxin-producing Escherichia coli (VTEC) and E. coli O157:H7 in beef in Sweden determined by PCR assays and an immunomagnetic separation (IMS) method. Food Microbiology 15, 591-601.

Lipsky, R.H.; Mazzanti, C.M.; Rudolph, J.G.; Xu, K.; Vyas, G. and Bozak, D. (2001): DNA melting analysis for detection of single nucleotide polymorphisms. Clin. Chem., 47, 635-644

Little, C.L. and De Louvois, J. (1998): The microbiological examination of butchery products and butcher's premises in the United Kingdom. Journal of Applied Microbiology 85, 177-186.

Malorny, B.; Tassios, P.T.; Rådström, P.; Cook, N.; Wagner, M. and Hoorfar, J. (2004a): Standardization of diagnostic PCR for the detection of foodborne pathogens. Int. J. Food Microbiol. 83:39-48.

Meng, J.; Doyle, M.P.; Zhao, T. and Zhao, S. (2007): Enterohemorrhagic Escherichia coli. In Doyle, M.P., and Beuchat, L.R. (Eds.). Food microbiology.Fundamentals and frontiers, 3rd edition, pp. 249-269.

Michino, H.; Araki, K.; Minami, S.; Nakayama, T.; Ejima, Y.; Hiroe, K.; Tanaka, H.; Fujita, N.; Usami, S.; Yonekawa, M.; Sadomoto, K.; Takaya, S. and Sakai, N. (1998): Recent outbreaks of infections caused by Escherichia coli O157:H7 in Washington D.C, pp. 73-81.

Mohammed, F. (2011): The incidence of Enterobacteriaceae causing food poisoning in some meat products. Advance Journal of food science and technology 3(2): 116-121.

Monis, PT. (2004): Comparison of SYTO9 and SYBR Green I for real-time Polymerase Chain Reaction and investigation of the effect of dye concentration on amplification and
DNA melting curve analysis. Analytical Biochemistry. 340: 24-34.

Mor-Mur, M. and Yuste, J. (2010): Emerging Bacterial Pathogens in Meat and Poultry: An Overview. Food Bioprocess \& Technology 3: 24-35.

Narang, N.; Fratamico, P.M.; Tillman, G.; Pupedis, K. and Cray, W.C. Jr (2009): Performance comparison of a fliC $(\mathrm{h} 7)$ real-time PCR assay with an $\mathrm{H} 7$ latex agglutination test for confirmation of the H type of Escherichia coli O157:H7. J. Food Prot., 72: 2195-2197.

Nataro, J.P. and Kaper, J.B. (1998): Diarrheagenic Escherichia coli. Clinical Microbiology Reviews. 11(1): 142-201.

Navas, J.; Ortiz, S.; Lopez, P.; Jantzen, MM.; Lopez, $V$. and Martinez-Suarez, JV. (2006): Evaluation of effects of primary and secondary enrichment for the detection of Listeria monocytogenes by real-time PCR in retail ground chicken meat. Foodborne Pathog Dis 3: 347-354.

Ochoa, T.J. and Cleary, T.G. (2003): Epidemiology and spectrum of disease of Escherichia coli O157.Curr.Opin. Infect. Dis., 16: 259-263.

Paton, AW. and Paton, JC. (1998): Detection and Characterization of Shigatoxigenic Escherichia coli by Using Multiplex PCR Assays for stx 1 , stx 2 , eae $A$, Enterohemorrhagic E. coli hlyA, rfbO111, and rfbO157. J. Clin. Microbiol., 36: 598-602.

Perelle, S.; Dilasser, F.; Grout, J. and Fach, P. (2007): Screening food raw materials for the presence of the world's most frequent clinical cases of Shiga toxin-encoding Escherichia coli $\mathrm{O} 26, \mathrm{O} 103, \mathrm{O} 111, \mathrm{O} 145$ and O157. Int. J. Food Microbiol.; 113: 284- 288.

Pochop1; Miroslava Kačániová1; Lukáš Hlebal; LubomírLopašovský; Katarína Rovná3 and HenrietaArpášová (2012): Application of Real-time PCR for Rapid Petection of Salmonella spp., Salmonella entericaser. Typhimurium and Enteritidis in Food Samples of Animal Origin without Pre-enrichment and with Pre-enrichment Scientific Papers: Animal Science and Biotechnologies, 2012, 45 (1) 341-345.

Podpecan, B.; Pengov, A. and Vadnjal, S. (2007): The source of contamination of ground meatfor production of meatproducts with bacteria staphylococcus aureussolv Vet. Res., 44: 25-30.

Quinn, P.J.; Carter, M.E.; Markey, B.K. and Carter, G.R. (1994): Clinical Veterinary Microbiology. Mosby. Yearbook Europe Limited.

Rahimi H. Momtaz; Mohammad HosseiniAnari, M.; Alimoradi, M.; Momeni, M. and Riahi, M. (2012): Isolation and genomic 
characterization of Escherichia coli O157:NM and Escherichia coli $\mathrm{O} 157: \mathrm{H} 7$ in minced meat and some traditional dairy products in Iran. African Journal of Biotechnology Vol. 11 (9), pp. 2328-2332.

Ram, S.; Vajpayee, P.; Tripathi, U.; Singh, R.L.; Seth, P.K. and Shanker, R. (2008): Determination of antimicrobial resistance and virulence gene signatures in surface water isolates of Escherichia coli. J. Applied Microbiol., 105: 1899-1908.

Ririe, K.M.; Rasmussen, R.P. and Witter, C.T. (1997): Product differentiation by analysis of DNA melting curves during the polymerase chain reaction. Anal.Biochem., 65, 1370-1372

Rodriguez-Lazaro, D. and Hernandez, M. (2006): Isolation of Listeria monocytogenes DNA from meat products for quantitative detection by real-time PCR. J Rapid Method Automat Microbio 14: 395-404.

Saleh, S.K. (2001): Prevalence of enterohaemorhagic Escherichia coli in some meat products. J. Egypt. Vet. Med. Ass., 61(4): 173-178.

Samadpour, M.; Kubler, M.; Buck, F.C.; Depavia, G.A.; Mazengia, E.; Stewart, J.; Yang, P. and Alfi, D. (2002): Prevalence of shiga toxin producing Escherichia coli in ground beef and cattle faeces from King County, Washington. J. Food Prot. 65, 1322-1325.

Savoye, F.; Feng, P.; Rozand, C.; Bouvier, M.; Gleizal, A. and Thevenot, D. (2012): Comparative evaluation of a phage protein ligand assay with real-time PCR and a reference method for the detection of Escherichia coli $\mathrm{O} 157: \mathrm{H} 7$ in raw ground beef and trimmings. J. Food Prot.,; 74: 6-12.

Seran Temelli; AyşegulEyigor and ŞahseneAnar (2012): Prevalence of Escherichia coli O157 in red meat and meat products determined by VIDAS ECPT and LightCycler PCR .Turk. J. Vet. Anim. Sci.; 36(3): 305-310.

Stampi, S.; Caprioli, A.; De Luca, G.; Quaglio, P., Sacchetti, R. and Zanetti, F. (2004): Detection of Escherichia coli $\mathrm{O} 157$ in bovine meat products in northern Italy Int $\mathrm{J}$ Food Microbiol. Feb 1; 90(3): 257-62.

Stannard, C. (1997): Development and use of microbiological criteria for foods. Food Technol. Today 11: 137-177

Suo, B.; He, Y.; Tu, S.I. and Shi, X. (2010): A multiplex real-time polymerase chain reaction for simultaneous detection of Salmonella spp., Escherichia coli 0157, and Listeria monocytogenesin meat products. Foodborne Pathog. Dis., 7: 619-628.

Tarr, P.I.; Tran, N.T. and Wilson, R.A. (1999): Escherichia coli O157:H7 in retail ground beef in Seattle: Results of a one-year prospective study. Journal of Food Protection 62 (2), 133-139.

United States Department of Agriculture; Food Safety Inspection Services, (2010a.): Detection, isolation and identificatrion of $\mathrm{E}$ coli 157 from meat products MLG5.05

United States Department of Agriculture; Food Safety Inspection Services (2010b): FSIS procedure for the use of $E$ coli 0157 screening MLG5.2

Van Donkersgoed, J.; Graham, T. and Gannon, V. (1999): The prevalence of verotoxins, Escherichia coli O157:H7 and Salmonella in the faeces and rumen of cattle at processing. Can. Vet. J. 40, 322-338.

Vernozy-Rozand, C.; Ray-Gueniot, S.; Ragot, C.; Bavai, C.; Mazuy, C.; Montet, M.P.; Bouvet, $J$. and Richard, Y. (2002): Prevalence of Escherichia coli O157:H7 in industrial mince beef. Lett. Appl. Microbiol. 35, 7-11.

Walsh, L.; Dooge, D. and Hill, C. (1997): Screening for Escherichia coli O157:H7 in Irish ground beef using two commercial detection systems. Irish Vet. J. incorporating Irish Vet. Times 50, 111-115.

Washington, DC.; ASM, USA. and Monis, PT. (2004): Comparison of SYTO9 and SYBR Green I for real-time Polymerase Chain Reaction and investigation of the effect of dye concentration on amplification and DNA melting curve analysis. Analytical Biochemistry. 340: 24-34.

Willshaw, G.A.; Thirwell, J.; Jones, A.P.; Parry, S.; Salmon, R.L. and Hickey, M. (1994): Verocytotoxin producing E. coli O157 in beef burgers linked to an outbreak of diarrhoea, haemorrhagic colitis and haemolyticuraemic syndrome. Lett. Appl. Microbiol. 19, 304-307.

$W u$ VCH (2008): A review of microbial injury and recovery methods in food. Food Microbiol 25:735-744.

Yoshimasa, Y. (2002): PCR in diagnosis of infection: Detection of bacteria in cerebrospinal fluids Clin. Diagnostic Lab. Immunol., 9: 508-514.

Zaki-Eman, M.S. (1990): Escherichia coli in meat products with special reference to Enteropathogenic strains. M.V.Sc. Thesis, Faculty of Veterinary Medicine, Cairo University, Egypt. 
مقارنة بين الطرق التقليدية وتفاعل انزيم البلمرة المتسلسل ذو الوقت الحقيقى فى كثف الاشريشيا كولاى في منتجات اللحوم البقرية

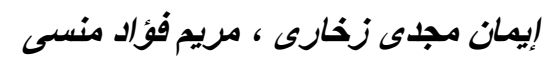

اجريت هذة الدراسة لمقارنة ددى انتشار الاشيرشيا كو لاى في اللحم المفروم والسجق باستخدام الأساليب التقليدية وتفاعل انزيم البلمرة

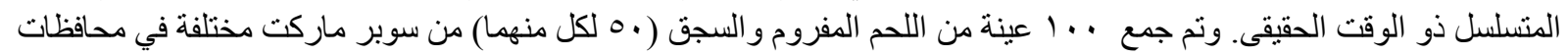

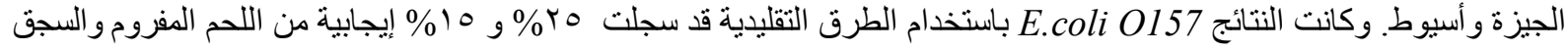

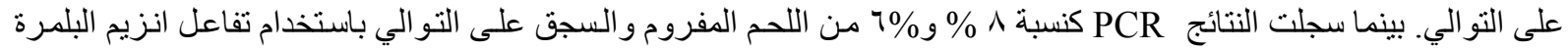

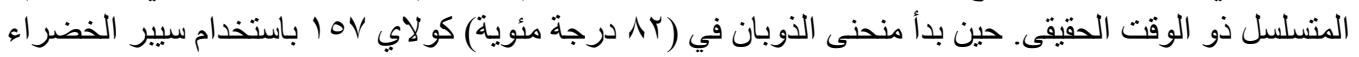

